\title{
Karakter Percabangan Malai Genotipe Padi Sawah pada Berbagai Level Dosis Fosfor
}

\section{Panicle Branching Traits of Lowland Rice Genotypes at Various Phosphorus Levels}

\author{
Tri Hastini', Willy Bayuardi Suwarno ${ }^{2}$, Munif Ghulamahdi ${ }^{2}$, dan Hajrial Aswidinnoor ${ }^{2 *}$
}

${ }^{1}$ Program Studi Pemuliaan dan Bioteknologi Tanaman, Sekolah Pascasarjana, Institut Pertanian Bogor

${ }^{2}$ Departemen Agronomi dan Hortikultura, Fakultas Pertanian, Institut Pertanian Bogor

(Bogor Agricultural University), J1. Meranti, Kampus IPB Darmaga, Bogor 16680, Indonesia

Diterima 15 Februari 2019/Disetujui 14 Mei 2019

\begin{abstract}
Grain yield of rice was determined by genetic and environmental factors; one of these was genetic response on levels of phosphorus. Rice panicle branching was one of the key factors supporting rice yield. The study aimed to understand the rice panicle branching responses to phosphorus levels. A controlled experiment was conducted from September 2017 to February 2018 using two genotypes planted on poor soil media and six levels of phosphorus as treatments, arranged in a completely randomized design. Panicle branching traits were observed in the experiment. The experiment showed significant genotypic effects on all panicle branching traits except for number of tertiary branches and number of grains on tertiary branches. Phosphorus levels affected panicle branching except panicle length, primary branch length, and number of grain on tertiary branches. Genotype by phosphorus interaction appeared at all panicle branching traits except number of primary branches, number of tertiary branches, number of grains on tertiary branches, and the percentage of grains number on tertiary branches. The panicle of genotype IPB180-12 was likely more stable to varying levels of phosphorus, whereas the panicle of IPB158-5 was more sensitive. According to the polynomial regression evaluation, the optimum level of $P_{2} O_{5}$ for the sensitive genotype was $421.63 \mathrm{~kg} \mathrm{ha}^{-1}$, and for the tolerant genotype was $108 \mathrm{~kg} \mathrm{ha}^{-1}$ in poor soil.
\end{abstract}

Keywords: genotype x phosphorus interaction, Oryza sativa, panicle branching, quadratic regression

\section{ABSTRAK}

Hasil padi ditentukan oleh faktor genetik dan lingkungan, salah satunya adalah respon genetik terhadap dosis fosfor. Salah satu karakter pendukung hasil adalah karakter percabangan malai. Penelitian ini bertujuan untuk mengetahui respon percabangan malai padi sawah terhadap pemberian dosis fosfor. Percobaan dilakukan secara terkontrol di rumah plastik pada bulan September 2017-Februari 2018, menggunakan dua genotipe yang ditanam pada media tanah yang kurus dan enam level dosis fosfor sebagai perlakuan. Rancangan percobaan yang digunakan adalah rancangan acak lengkap faktorial dengan tiga ulangan. Pengamatan dilakukan terhadap karakter percabangan malai. Hasil percobaan menunjukkan bahwa genotipe berpengaruh nyata kecuali pada karakter jumlah cabang tersier dan jumlah gabah cabang tersier. Dosis fosfor berpengaruh nyata pada semua karakter kecuali panjang malai, panjang cabang primer, dan jumlah gabah cabang tersier. Terdapat interaksi genotipe dan fosfor pada seluruh karakter kecuali pada karakter jumlah cabang primer, jumlah cabang tersier, jumlah gabah cabang tersier dan persentase gabah cabang tersier. Respon percabangan malai genotipe IPB180-12 diduga lebih stabil terhadap berbagai dosis $P$, sedangkan IPB158-5 lebih sensitif. Dosis $P_{2} O_{5}$ yang optimum untuk genotipe yang sensitif adalah $421.63 \mathrm{~kg} \mathrm{ha}^{-1}$, dan untuk genotipe yang toleran adalah $108 \mathrm{~kg} \mathrm{ha}^{-1}$ pada tanah miskin unsur hara.

Kata kunci: interaksi genotipe x fosfor, Oryza sativa, percabangan malai, regresi kuadratik

\section{PENDAHULUAN}

Hara makro fosfor (P) berperan penting dalam pertumbuhan tanaman padi. Unsur P mempunyai pengaruh yang nyata pada jumlah anakan, bahan kering tanaman baik bagian akar maupun batang, laju pertumbuhan dan

\footnotetext{
* Penulis untuk korespondensi. e-mail: hajrial@apps.ipb.ac.id
}

konsentrasi P batang (Kekulandara et al., 2017). Pada batang terlihat interaksi yang nyata antara unsur P dan $\mathrm{Zn}$ dengan genotipe pada fase pembentukan anakan. Pada daun, interaksi tersebut nyata pada fase pembentukan anakan dan heading, sedangkan pada malai, interaksi terlihat nyata pada saat heading (Amanullah dan Inamullah, 2016).

Amanullah dan Inamullah (2016) melaporkan bahwa dengan pemberian dosis $\mathrm{P}$ yang tinggi (120 kg ha-1 TSP) pada saat tanam, konsentrasi $\mathrm{P}$ akan ditemukan paling 
banyak pada malai dibandingkan pada daun maupun batang pada fase heading maupun fase masak fisiologis. Unsur P secara nyata juga memperbaiki jumlah anakan produktif, bobot 1,000 butir dan hasil pada tanaman padi (Rehim et al., 2014). Penambahan $\mathrm{P}$ menunjukkan pengaruh yang sangat nyata pada karakter jumlah gabah per malai yang selanjutnya berkontribusi kepada peningkatan hasil padi (Yoseftabar, 2013; Jeong et al., 2017). Nadeem et al. (2015) juga menyatakan pengaruh positif $\mathrm{P}$ terhadap panjang malai dan jumlah gabah total per malai. Namun demikian, belum ditemukan laporan mengenai pengaruh $\mathrm{P}$ terhadap percabangan malai atau respon genotipe malai padi terhadap P. Oleh sebab itu, perlu diketahui lebih jauh respon karakter percabangan malai genotipe padi yang berbeda pada berbagai level dosis P. Penelitian ini bertujuan untuk mengetahui perilaku percabangan malai dari genotipe yang berbeda pada beberapa level dosis $\mathrm{P}$.

\section{BAHAN DAN METODE}

Percobaan secara terkontrol respon percabangan malai padi sawah terhadap fosfor dilakukan di rumah plastik di Kebun Percobaan Babakan, Dramaga, Bogor pada bulan September 2017 sampai dengan Februari 2018. Media tanah yang digunakan untuk percobaan merupakan tanah merah berasal dari perbukitan Desa Gunung Galuga Kecamatan Cibungbulang Kabupaten Bogor. Hasil analisis laboratorium menunjukkan bahwa kandungan unsur hara $\mathrm{P}$ rendah, yaitu $\mathrm{P}$ total $9.28 \mathrm{mg} \mathrm{P}_{2} \mathrm{O}_{5} 100 \mathrm{~g}^{-1}$ (analisis dengan ekstrak $\mathrm{HCl}$ $25 \%$ ) dan $\mathrm{P}$ tersedia 0.14 ppm $\mathrm{P}_{2} \mathrm{O}_{5}$ (analisis dengan ekstrak Olsen). Percobaan disusun dalam rancangan acak lengkap (RAL) faktorial dengan faktor pertama genotipe (G) dan faktor kedua dosis pupuk $\mathrm{P}$ dan diulang tiga kali. Setiap unit percobaan (kombinasi genotipe dan dosis $\mathrm{P}_{2} \mathrm{O}_{5}$ ) berisi tiga ember pada setiap ulangan. Penanaman untuk pengamatan perkembangan perakaran hanya dilakukan pada dosis $\mathrm{P}_{2} \mathrm{O}_{5}$ 0, 108, dan $648 \mathrm{~kg} \mathrm{ha}^{-1}$ masing-masing tiga ember. Bibit ditanam pada umur 14 hari setelah semai (hss).

Pada percobaan ini, faktor genotipe sebagai perlakuan dipilih yang mempunyai sifat percabangan malai sangat kontras dan faktor dosis P dibuat sangat ekstrim. Sebagai perlakuan digunakan genotipe IPB158-5 dan IPB180-12 serta taraf dosis P 0 (kontrol), $108 \mathrm{~kg} \mathrm{P}_{2} \mathrm{O}_{5} \mathrm{~kg} \mathrm{ha}^{-1}, 216 \mathrm{~kg}$ $\mathrm{P}_{2} \mathrm{O}_{5} \mathrm{~kg} \mathrm{ha}^{-1}, 324 \mathrm{~kg} \mathrm{P}_{2} \mathrm{O}_{5} \mathrm{~kg} \mathrm{ha}^{-1}, 432 \mathrm{~kg} \mathrm{P}_{2} \mathrm{O}_{5} \mathrm{~kg} \mathrm{ha}^{-1}, 540$ $\mathrm{kg} \mathrm{P_{2 }} \mathrm{O}_{5} \mathrm{~kg} \mathrm{ha}^{-1}$ dan $648 \mathrm{~kg} \mathrm{P}_{2} \mathrm{O}_{5} \mathrm{~kg} \mathrm{ha}^{-1}$. Pupuk $\mathrm{P}$ berupa SP36 diberikan sehari sebelum tanam. Selanjutnya pupuk N dalam bentuk Urea sebanyak 0.575 g per ember $\mathrm{N}$ diberikan tiga kali pada umur 7 hari setelah tanam (separuh dosis), 30 hari setelah tanam dan 45 hari setelah tanam (masingmasing seperempat dosis) serta pupuk $\mathrm{K}$ dalam bentuk $\mathrm{KCl}$ ( $0.225 \mathrm{~g} \mathrm{~K}_{2} \mathrm{O}$ per ember) diberikan pada umur 7 hari setelah tanam dan pada umur 30 hari setelah tanam masing-masing separuh dosis.

Genotipe IPB158-5 mempunyai latar belakang genetik malai yang pendek dan relatif banyak jumlah cabang tersier, sedangkan genotipe IPB180-12 mempunyai malai yang panjang dan relatif sedikit atau tidak mempunyai cabang tersier. Pengamatan dilakukan terhadap karakter percabangan malai yaitu panjang malai (PM), jumlah cabang primer malai (JCP), panjang rata-rata cabang primer malai (PCP), jumlah cabang sekunder malai (JCS), panjang ratarata cabang sekunder malai (PCS), jumlah cabang sekunder per cabang tersier (JCS CP-1), jumlah cabang tersier malai (JCT), jumlah gabah total per malai (JGT), jumlah gabah per cabang primer $\left(\mathrm{JG} \mathrm{CP}^{-1}\right)$, jumlah gabah per cabang sekunder (JG CS ${ }^{-1}$ ), jumlah gabah yang terdapat pada cabang tersier per malai (JGCT) dan persentase jumlah gabah tersier dalam satu malai (\%GCT). Pengamatan dilakukan terhadap seluruh malai yang keluar dari batang utama, anakan primer dan anakan sekunder. Sebagai penunjang, dilakukan pengamatan tinggi tanaman (TT) dan perkembangan akar pada dosis $\mathrm{P}_{2} \mathrm{O}_{5}$ $108 \mathrm{~kg} \mathrm{ha}^{-1}$ dan $648 \mathrm{~kg} \mathrm{ha}^{-1}$ pada umur 55 hari setelah semai (hss). Data dianalisis ragam menggunakan program STAR dari IRRI. Analisis pola respon dan korelasi menggunakan Minitab versi 14 dan pembuatan grafik menggunakan Excel 2013. Analisis lanjutan dilakukan dengan DMRT taraf 5\% untuk mengetahui perbedaan antar perlakuan dan analisis regresi polinomial untuk mengetahui pola respon.

\section{HASIL DAN PEMBAHASAN}

Hasil percobaan menunjukkan terdapatnya pengaruh genotipe, dosis $\mathrm{P}$, dan interaksi $\mathrm{G}$ x $\mathrm{P}$ pada sejumlah karakter. Genotipe umumnya menunjukkan pengaruh sangat nyata pada semua karakter pengamatan kecuali pada jumlah cabang tersier dan jumlah gabah cabang tersier. Dosis $\mathrm{P}$ berpengaruh nyata sampai sangat nyata pada karakter jumlah gabah total, jumlah cabang primer, jumlah cabang sekunder, panjang cabang sekunder, jumlah cabang sekunder per cabang primer, jumlah cabang tersier, jumlah gabah per cabang primer, jumlah gabah per cabang sekunder, dan persentase jumlah gabah cabang tersier per malai, sementara interaksi G x P terdapat pada panjang malai, jumlah gabah total, panjang cabang primer, jumlah cabang sekunder, panjang cabang sekunder, jumlah cabang sekunder per cabang primer, jumlah gabah per cabang primer, dan jumlah gabah per cabang sekunder (Tabel 1). Hasil anova mengindikasikan bahwa genotipe padi lebih berpengaruh terhadap karakter percabangan malai padi dibandingkan dosis fosfor. Hal ini sejalan dengan hasil percobaan Rahayu et al. (2018) yang melaporkan bahwa genotipe IPB175-F-71-1 (sedikit cabang primer) dan IPB175-F-31-2-1 (banyak cabang primer) tidak menunjukkan respon yang nyata terhadap pemberian nitrogen dan karakter percabangan malai lebih dipengaruhi oleh genotipe.

Tanaman pada dosis $\mathrm{P}$ terendah yaitu $0 \mathrm{~kg} \mathrm{ha}^{-1}$ tidak mengalami perkembangan dan mati sebelum memasuki fase generatif sehingga tidak dianalisis lebih lanjut. Hal ini disebabkan tersedianya unsur hara $\mathrm{P}$ untuk perkembangan akar sangat rendah $(<10 \mathrm{ppm})$. Kondisi ini serupa dengan hasil penelitian Fageria et al. (2013) pada kultivar padi BRS Jaburu. Seperti diketahui bahwa fungsi P pada tanaman padi salah satunya adalah memacu perkembangan akar pada awal masa pertumbuhan; tidak terdapatnya metabolisme $\mathrm{P}$ akan menghambat perkembangan akar (Peret et al., 2014; Vejchasarn et al., 2016). Perkembangan perakaran tanaman 
Tabel 1. Rekapitulasi sidik ragam karakter percabangan malai padi pada percobaan fosfor di rumah plastik

\begin{tabular}{|c|c|c|c|c|c|}
\hline Karakter & Rata-rata $\pm \mathrm{SD}$ & $\begin{array}{l}\text { Koefisien } \\
\text { keragaman }\end{array}$ & $\begin{array}{l}\text { Nilai p } \\
\text { genotipe }\end{array}$ & $\begin{array}{l}\text { Nilai p } \\
\text { dosis P }\end{array}$ & $\begin{array}{l}\text { Nilai } \mathrm{p} \text { interaksi } \\
\text { dosis } \mathrm{P} \times \text { genotipe }\end{array}$ \\
\hline PM & $24.47 \pm 1.66$ & 3.06 & $0.000 * *$ & 0.420 tn & $0.023 *$ \\
\hline JGT & $205.49 \pm 46.28$ & 7.99 & $0.000 * *$ & $0.017^{*}$ & $0.030 *$ \\
\hline JCP & $10.64 \pm 1.35$ & 3.93 & $0.000 * *$ & $0.017 *$ & $0.501 \mathrm{th}$ \\
\hline PCP & $12.85 \pm 1.06$ & 3.97 & $0.000 * *$ & $0.091 \mathrm{tn}$ & $0.045^{*}$ \\
\hline JCS & $38.06 \pm 8.18$ & 7.45 & $0.000 * *$ & $0.015^{*}$ & $0.017 *$ \\
\hline PCS & $3.25 \pm 0.15$ & 3.17 & $0.000 * *$ & $0.047 *$ & $0.017 *$ \\
\hline JCS CP-1 & $3.49 \pm 0.40$ & 6.08 & $0.000 * *$ & $0.040 *$ & $0.002 * *$ \\
\hline JCT & $1.74 \pm 1.14$ & 57.49 & $0.830 \mathrm{tn}$ & $0.045^{*}$ & 0.148 tn \\
\hline JG CP-1 & $18.04 \pm 2.17$ & 6.23 & $0.000 * *$ & $0.009 * *$ & $0.007 * *$ \\
\hline JG CS-1 & $3.75 \pm 0.17$ & 3.03 & $0.000 * *$ & $0.000 * *$ & $0.017^{*}$ \\
\hline JGCT & $3.99 \pm 2.74$ & 60.62 & 0.990 tn & $0.052 \mathrm{tn}$ & 0.144 tn \\
\hline$\% \mathrm{GCT}$ & $1.54 \pm 0.95$ & 47.74 & $0.014 *$ & $0.028^{*}$ & $0.051 \mathrm{th}$ \\
\hline
\end{tabular}

Keterangan: $\mathrm{SD}=$ Standar deviasi; $\mathrm{PM}=$ panjang malai; JGT = jumlah gabah total; JCP = jumlah cabang primer per malai; $\mathrm{PCP}=$ panjang cabang primer; JCS $=$ jumlah cabang sekunder per malai; $\mathrm{PCS}=$ panjang cabang sekunder; $\mathrm{JCS} \mathrm{CP}^{-1}=$ jumlah cabang sekunder per cabang primer; $\mathrm{JCT}=$ jumlah cabang tersier; $\mathrm{JG} \mathrm{CP}^{-1}=$ jumlah gabah per cabang primer; $\mathrm{JG} \mathrm{CS}^{-1}=$ jumlah gabah per cabang sekunder; JGCT = jumlah gabah pada cabang tersier per malai; \%GCT = persentase gabah pada cabang tersier per malai; $\mathrm{kk}=$ koefisien keragaman; $*$ = berpengaruh nyata pada $\alpha=0.05 ; * *=$ berpengaruh nyata pada $\alpha=0.01 ; \mathrm{tn}=$ tidak berpengaruh nyata berdasarkan uji $\mathrm{F}$

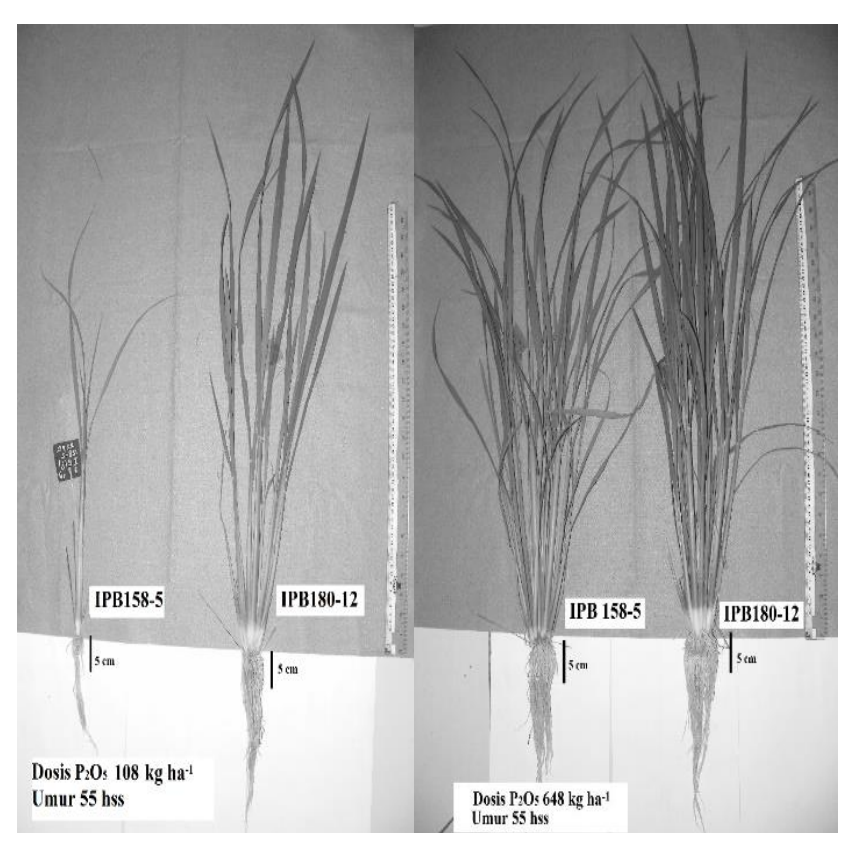

Gambar 1. Perkembangan akar dosis $\mathrm{P}_{2} \mathrm{O}_{5} 108 \mathrm{~kg} \mathrm{ha}^{-1}$ lebih terhambat dibandingkan dosis $648 \mathrm{~kg} \mathrm{ha}^{-1}$ pada genotipe IPB158-5 dan 180-12 umur 55 hari setelah semai (hss). Pada dosis $\mathrm{P}_{2} \mathrm{O}_{5} 108 \mathrm{~kg} \mathrm{ha}^{-1}$ panjang akar IPB158-5 $24.75 \mathrm{~cm}$ dengan bobot kering matahari $4.45 \mathrm{~g}$, sedangkan panjang akar IPB180-12 25.67 $\mathrm{cm}$ dengan bobot kering matahari $4.50 \mathrm{~g}$. Pada dosis $\mathrm{P}_{2} \mathrm{O}_{5} 648 \mathrm{~kg} \mathrm{ha}^{-1}$ panjang akar IPB158-5 $23.83 \mathrm{~cm}$ dengan bobot kering matahari $14.17 \mathrm{~g}$, sedangkan panjang akar IPB180-12 $28.33 \mathrm{~cm}$ dengan bobot kering matahari 13.57 g. Data merupakan rata-rata dari tiga tanaman. pada dosis terkecil $\left(108 \mathrm{~kg} \mathrm{ha}^{-1} \mathrm{P}_{2} \mathrm{O}_{5}\right)$ dan dosis terbesar (648 $\mathrm{kg} \mathrm{ha}^{-1} \mathrm{P}_{2} \mathrm{O}_{5}$ ) pada umur 55 hss disajikan pada Gambar 1, sedangkan penampilan malai setiap rumpun pada genotipe IPB158-5 dan IPB180-12 pada berbagai level dosis P disajikan pada Gambar 2.

Tabel 2 memberikan informasi lebih mendalam mengenai interaksi $\mathrm{G} \times \mathrm{P}$ pada karakter panjang malai, jumlah gabah total, panjang cabang primer, jumlah cabang sekunder, panjang cabang sekunder, jumlah cabang sekunder per cabang primer, dan jumlah gabah per cabang sekunder. Pengaruh interaksi $\mathrm{G} \times \mathrm{P}$ terlihat lebih besar pada genotipe IPB158-5 dibandingkan genotipe IPB180-12 pada karakter jumlah cabang sekunder, panjang cabang sekunder, jumlah cabang sekunder per cabang primer, jumlah gabah total per malai, jumlah gabah per cabang primer dan jumlah gabah per cabang sekunder. Pada genotipe IPB180-12, terlihat nilai pengamatan yang kecil pada berbagai karakter percabangan malai pada dosis $\mathrm{P}$ tertinggi $\left(648 \mathrm{~kg} \mathrm{ha}^{-1} \mathrm{P}_{2} \mathrm{O}_{5}\right)$ serupa dengan dosis terendah $\left(108 \mathrm{~kg} \mathrm{ha}^{-1} \mathrm{P}_{2} \mathrm{O}_{5}\right)$. Hasil penelitian yang sama dilaporkan oleh Bustami et al. (2012), diduga pemberian $P$ yang terlalu tinggi justru dapat menekan pertumbuhan tanaman dan kelebihan pupuk yang diberikan tidak dapat seluruhnya dimanfaatkan oleh tanaman. Penambahan $\mathrm{P}$ secara berlebihan menjadi tidak efektif terhadap panjang dan bobot malai (Panda et al., 2012). Pemberian pupuk P dalam jumlah besar justru mendorong besarnya fiksasi $\mathrm{P}$ oleh tanah dan tidak dapat dimobilisasi sehingga hanya sedikit $\mathrm{P}$ yang dapat dimanfaatkan oleh tanaman serta menyebabkan perubahan tekstur tanah dan $\mathrm{pH}$ (Kakade et al., 2017). 

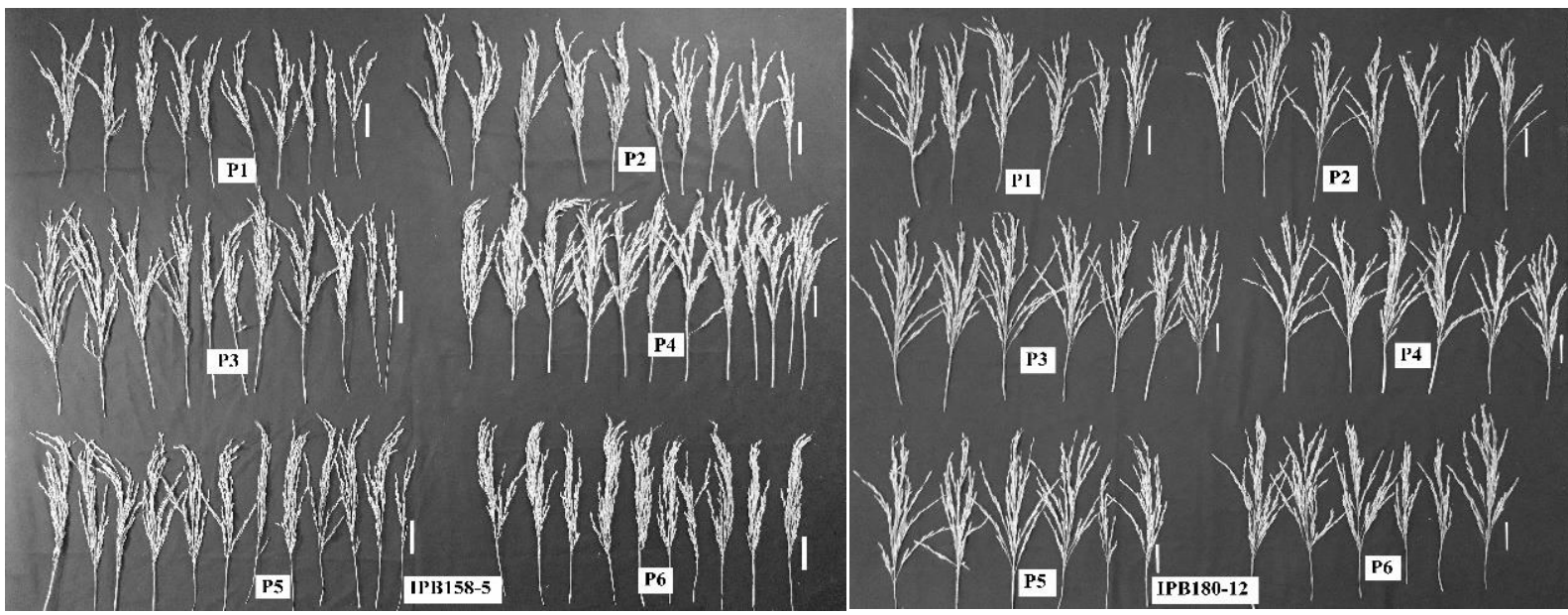

Gambar 2. Malai genotipe IPB158-5 berbeda nyata, dan malai genotipe IPB180-12 tidak berbeda nyata pada berbagai level dosis $\mathrm{P}_{2} \mathrm{O}_{5}$ $\left(\mathrm{kg} \mathrm{ha}^{-1}\right) . \mathrm{P} 1=108 ; \mathrm{P} 2=216 ; \mathrm{P} 3=324 ; \mathrm{P} 4=648 ; \mathrm{P} 5=540 ; \mathrm{P} 6=648$. Tanda strip menunjukkan skala $5 \mathrm{~cm}$

Fageria et al. (2013) melaporkan pengaruh $\mathrm{P}$ yang secara nyata meningkatkan panjang malai. Aktivitas P pada biji lebih besar daripada aktivitas $\mathrm{P}$ pada daun, sekam, anakan terakhir, sumbu utama malai dan daun bendera meskipun lebih kecil daripada aktivitas P pada batang (Julia et al., 2016). Atakora et al. (2015) juga menyatakan bahwa unsur P secara nyata meningkatkan jumlah malai produktif per tanaman dan meningkatkan hasil tanaman. Pengaruh nyata unsur $\mathrm{P}$ terhadap karakter percabangan malai padi diduga karena proses fisiologis yang menjelaskan bahwa terdapat lebih banyak partisi bahan kering ke dalam bagian reproduktif tanaman yaitu malai (Amanulloh dan
Inamullah, 2016). Sejauh ini, belum ditemukan laporan yang secara khusus membahas pengaruh $\mathrm{P}$ terhadap karakter percabangan malai.

Penampilan fenotipik tanaman merupakan hasil interaksi antara faktor genetik $\times$ lingkungan. Percobaan pemberian $\mathrm{P}$ dengan berbagai dosis merupakan lingkungan tumbuh bagi tanaman padi. Weng et al. (2014) melaporkan ditemukannya gen yang bekerja untuk mengatur arsitektur tanaman sekaligus dapat merespon berbagai macam sinyal dari lingkungan yaitu Ghd7. Gen Ghd7 berperan dalam meregulasi gen-gen lain seperti $T C P$, $S P L$, dan $Y A B B Y$ yang terlibat dalam proses pengaturan percabangan malai.

Tabel 2. Nilai tengah karakter percabangan malai padi pada percobaan fosfor di rumah plastik yang dipengaruhi $\mathrm{G} \times \mathrm{P}$

\begin{tabular}{|c|c|c|c|c|c|c|c|c|}
\hline $\begin{array}{l}\text { Dosis } \mathrm{P}_{2} \mathrm{O}_{5} \\
\left(\mathrm{~kg} \mathrm{ha}^{-1}\right)\end{array}$ & PM & JGT & PCP & JCS & PCS & $\mathrm{JCS} \mathrm{CP}^{-1}$ & $\mathrm{JG} \mathrm{CP}^{-1}$ & $\mathrm{JG} \mathrm{CS}^{-1}$ \\
\hline \multicolumn{9}{|c|}{ Genotipe IPB158-5 } \\
\hline 108 & $21.71 \mathrm{~b}$ & $129.53 c$ & $11.11 \mathrm{~b}$ & $24.22 \mathrm{c}$ & $3.18 \mathrm{c}$ & $2.72 \mathrm{c}$ & $14.04 \mathrm{c}$ & $3.44 \mathrm{~d}$ \\
\hline 216 & $23.38 \mathrm{a}$ & $158.57 \mathrm{bc}$ & $11.83 \mathrm{ab}$ & $29.85 b$ & $3.32 \mathrm{abc}$ & $3.11 \mathrm{~b}$ & $15.88 b c$ & $3.61 \mathrm{bcd}$ \\
\hline 324 & $23.54 \mathrm{a}$ & $177.79 \mathrm{ab}$ & $12.55 \mathrm{a}$ & $33.21 \mathrm{ab}$ & $3.43 \mathrm{a}$ & $3.40 \mathrm{ab}$ & $17.42 \mathrm{ab}$ & $3.78 \mathrm{ab}$ \\
\hline 432 & $23.53 \mathrm{a}$ & $191.21 \mathrm{a}$ & $12.55 \mathrm{a}$ & $35.86 \mathrm{a}$ & $3.45 \mathrm{a}$ & $3.61 \mathrm{a}$ & $18.70 \mathrm{a}$ & $3.87 \mathrm{a}$ \\
\hline 540 & $23.22 \mathrm{a}$ & $169.46 \mathrm{ab}$ & $12.18 \mathrm{a}$ & $31.32 \mathrm{ab}$ & $3.38 \mathrm{ab}$ & $3.25 \mathrm{~b}$ & $16.93 \mathrm{ab}$ & $3.72 \mathrm{abc}$ \\
\hline 648 & $22.85 \mathrm{ab}$ & $157.61 \mathrm{bc}$ & $11.69 \mathrm{ab}$ & $29.97 b$ & $3.19 b c$ & $3.13 b$ & $15.86 \mathrm{bc}$ & $3.57 \mathrm{~cd}$ \\
\hline \multicolumn{9}{|c|}{ Genotipe IPB180-12 } \\
\hline 108 & $26.67 \mathrm{a}$ & $249.85 \mathrm{ab}$ & $14.07 \mathrm{a}$ & $46.19 \mathrm{ab}$ & $3.19 \mathrm{ab}$ & $4.00 \mathrm{a}$ & $20.00 \mathrm{ab}$ & $3.83 \mathrm{ab}$ \\
\hline 216 & $26.00 \mathrm{ab}$ & $229.51 b$ & $13.33 \mathrm{a}$ & $42.68 b$ & $3.03 b$ & $3.50 \mathrm{~b}$ & $18.01 \mathrm{~b}$ & $3.66 \mathrm{~b}$ \\
\hline 324 & $26.41 \mathrm{ab}$ & $265.42 \mathrm{a}$ & $14.21 \mathrm{a}$ & $48.42 \mathrm{a}$ & $3.26 \mathrm{a}$ & $3.91 \mathrm{a}$ & $20.76 a$ & $3.96 \mathrm{a}$ \\
\hline 432 & $25.25 b$ & $243.44 \mathrm{ab}$ & $13.48 \mathrm{a}$ & $44.68 \mathrm{ab}$ & $3.15 \mathrm{ab}$ & $3.67 \mathrm{ab}$ & $19.08 \mathrm{ab}$ & $3.82 \mathrm{ab}$ \\
\hline 540 & $25.60 \mathrm{ab}$ & $242.54 \mathrm{ab}$ & $13.60 \mathrm{a}$ & $44.99 \mathrm{ab}$ & $3.19 \mathrm{ab}$ & $3.81 \mathrm{ab}$ & $19.76 \mathrm{ab}$ & $3.83 \mathrm{ab}$ \\
\hline 648 & $25.50 \mathrm{ab}$ & $250.94 \mathrm{ab}$ & $13.64 \mathrm{a}$ & $45.30 \mathrm{ab}$ & $3.28 \mathrm{a}$ & $3.77 \mathrm{ab}$ & $20.00 \mathrm{ab}$ & $3.92 \mathrm{a}$ \\
\hline
\end{tabular}

Keterangan: $\mathrm{PM}=$ panjang malai; JGT = jumlah gabah total; $\mathrm{PCP}=$ panjang cabang primer; JCS = jumlah cabang sekunder per malai; $\mathrm{PCS}=$ panjang cabang sekunder; JCS CP${ }^{-1}=$ jumlah cabang sekunder per cabang primer; $\mathrm{JG} \mathrm{CP}^{-1}=$ jumlah gabah per cabang primer; $\mathrm{JG} \mathrm{CS}^{-1}=$ jumlah gabah per cabang sekunder; nilai yang diikuti oleh huruf yang sama tidak berbeda nyata berdasarkan uji DMRT pada taraf 5\% pada masing-masing genotipe 
Hubungan karakter percabangan malai terhadap jumlah gabah total per malai dapat diketahui dari korelasi karakter percabangan tersebut dengan jumlah gabah total per malai. Panjang malai, jumlah cabang primer, panjang cabang primer, jumlah cabang sekunder, jumlah cabang sekunder per cabang primer, jumlah gabah per cabang primer, jumlah gabah per cabang sekunder mempunyai mempunyai korelasi yang positif nyata terhadap jumlah gabah total per malai. Sebagai karakter yang menunjang percabangan malai, tinggi tanaman mempunyai korelasi yang positif nyata dengan panjang malai, jumlah gabah total, jumlah cabang primer, jumlah cabang sekunder, panjang cabang primer, jumlah gabah per cabang primer, jumlah gabah per cabang sekunder, dan jumlah cabang sekunder per cabang primer (Tabel 3). Beberapa studi melaporkan terdapat korelasi yang positif nyata antara tinggi tanaman dengan panjang malai (Mohamed et al., 2012; Norain et al., 2014). Zhang et al. (2017) melaporkan bahwa Oryza sativa japonica cv. Kita-ake dengan postur tanaman yang tinggi menghasilkan malai yang lebat namun lambat berbunga. Pada padi hibrida, tinggi tanaman justru berkorelasi negatif dengan umur berbunga (Kartina et al., 2017). Rasio panjang malai dengan tinggi tanaman pada genotipe IPB158-5 dan IPB 180-12 disajikan Gambar 3.

Pola interaksi $\mathrm{G} \times \mathrm{P}$ pada karakter percabangan malai serupa dengan hasil penelitian Vejchasarn et al. (2016) mengenai interaksi $\mathrm{G} \times \mathrm{P}$ pada karakter bobot biomasa, jumlah anakan dan kandungan $\mathrm{P}$ pada tanaman. Pola tersebut menjelaskan bahwa terdapat genotipe yang sangat sensitif oleh tinggi rendahnya $\mathrm{P}$, dan terdapat pula genotipe yang menunjukkan kestabilan pada $\mathrm{P}$ rendah maupun tinggi. Hal yang sama juga dilaporkan oleh Chiangmai dan Yodmingkhwan (2011). Pada penelitian ini, genotipe IPB158-5 termasuk ke dalam genotipe yang sangat dipengaruhi oleh dosis P, berbeda dengan IPB180-12. Hasil uji pola respon dengan regresi polinomial menunjukan perbedaan respon yang nyata antara genotipe IPB1585 dan IPB180-12. Genotipe IPB158-5 menunjukkan respon kuadratik pada semua karakter percabangan malai yang diamati (Gambar 4), sedangkan pola respon genotipe IPB180-12 umumnya tidak sesuai dengan model linier maupun kuadratik, kecuali pada jumlah cabang primer yang sesuai dengan model kuadratik. Pola respon kuadratik menjelaskan bahwa penambahan dosis $\mathrm{P}$ mampu meningkatkan nilai pengamatan hingga titik maksimum tertentu dan jika penambahan dosis P diteruskan, maka akan terjadi penurunan nilai. Berdasarkan pola respon kuadratik pada genotipe IPB158-5, dapat diketahui dosis optimum untuk mencapai jumlah gabah total per malai tertinggi (184.25 butir) adalah $421.63 \mathrm{~kg} \mathrm{ha}^{-1} \mathrm{P}_{2} \mathrm{O}_{5}$. Respon genotipe IPB180-12 mengindikasikan bahwa pemberian $\mathrm{P}$ dengan dosis $108 \mathrm{~kg} \mathrm{ha}^{-1} \mathrm{P}_{2} \mathrm{O}_{5}$ sudah bisa memberikan jumlah gabah total per malai yang tinggi, tidak berbeda dengan dosis yang lain.

Perbedaan antara genotipe IPB158-5 dan IPB180-12 dalam merespon unsur $\mathrm{P}$ serupa dengan hasil penelitian Mukherjee et al. (2014) dan Vejchasarn et al. (2016) bahwa serapan hara P bervariasi antar genotipe padi. Selanjutnya respon genotipe yang bervariasi terhadap unsur $\mathrm{P}$ dapat digunakan untuk pertimbangan dalam seleksi genotipe padi berdasarkan karakter percabangan malai yang toleran terhadap P rendah (Ahadiyat et al., 2014). Pada penelitian ini, malai genotipe IPB180-12 terlihat kurang terpengaruh oleh P. Diduga karakter percabangan malai genotipe IPB180-12 lebih stabil terhadap P, sehingga tidak terdapat perubahan nilai yang terlalu besar pada kondisi $\mathrm{P}$ rendah atau $\mathrm{P}$ tinggi.

Tabel 3. Nilai korelasi karakter percabangan malai dengan jumlah gabah total per malai

\begin{tabular}{|c|c|c|c|c|c|c|c|c|c|c|c|c|}
\hline & JGT & PM & $\mathrm{JCP}$ & PCP & JCS & PCS & $\begin{array}{c}\text { JC- } \\
\mathrm{SCP}^{-1}\end{array}$ & $\mathrm{JCT}$ & $\mathrm{JG} \mathrm{CP}^{-1}$ & $\mathrm{JG} \mathrm{CS}^{-1}$ & JGCT & $\% \mathrm{GCT}$ \\
\hline JGT & - & $0.964 * *$ & $0.965^{* *}$ & $0.988 * *$ & $0.999 * *$ & $-0.314 \mathrm{tn}$ & $0.941 * *$ & $0.354 \mathrm{tn}$ & $0.953 * *$ & $0.820 * *$ & 0.310 tn & $-0.127 \mathrm{tn}$ \\
\hline TT & $0.795 * *$ & $0.741 * *$ & $0.789 * *$ & $0.773 * *$ & $0.794 * *$ & $-0.092 \mathrm{tn}$ & $0.746 * *$ & $0.380 \mathrm{tn}$ & $0.775 * *$ & $0.741 * *$ & $0.343 \mathrm{tn}$ & $0.028 \mathrm{tn}$ \\
\hline
\end{tabular}

Keterangan: $\mathrm{PM}=$ panjang malai; JGT $=$ jumlah gabah total; $\mathrm{PCP}=$ panjang cabang primer; JCS $=$ jumlah cabang sekunder per malai; $\mathrm{PCS}=$ panjang cabang sekunder; JCS $\mathrm{CP}^{-1}=$ jumlah cabang sekunder per cabang primer; $\mathrm{JG} \mathrm{CP}^{-1}=$ jumlah gabah per cabang primer; $\mathrm{JG} \mathrm{CS}^{-1}=$ jumlah gabah per cabang sekunder; $\mathrm{TT}=$ tinggi tanaman; $* *=$ nyata pada $\alpha=0.01 ;$ th $=$ tidak nyata menurut uji korelasi Pearson
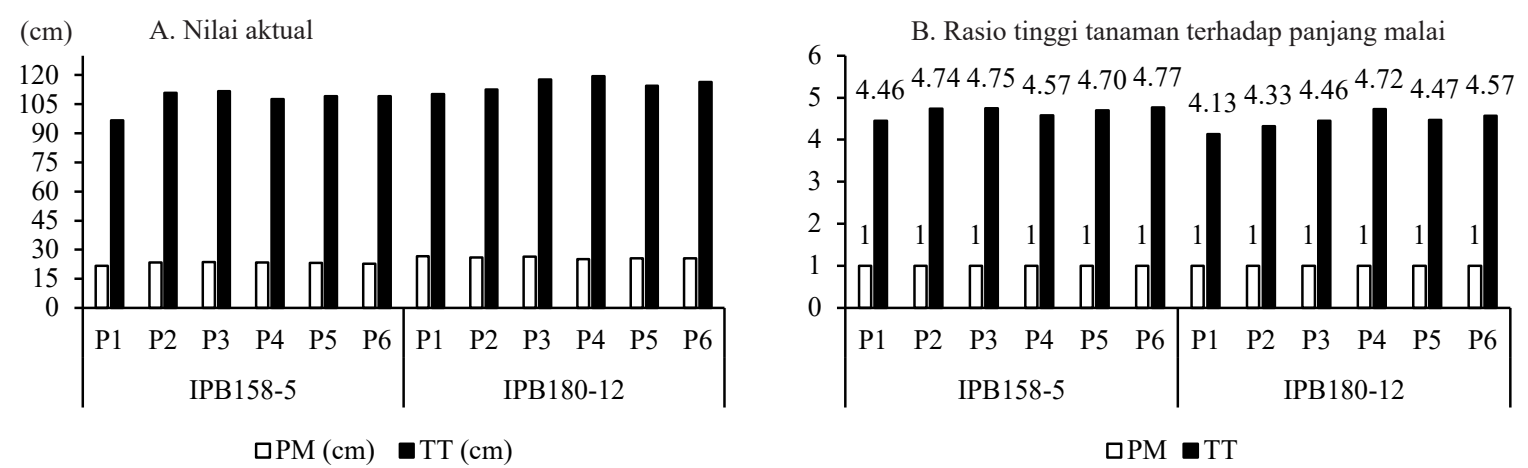

Gambar 3. Tinggi tanaman (TT) dan panjang malai (PM). P1 = 108; $\mathrm{P} 2=216 ; \mathrm{P} 3=324 ; \mathrm{P} 4=648 ; \mathrm{P} 5=540 ; \mathrm{P} 6=648\left(\mathrm{~kg}^{2} \mathrm{~h}^{-1} \mathrm{P}_{2} \mathrm{O}_{5}\right)$. A. Nilai aktual; B. Rasio tinggi tanaman terhadap panjang malai 

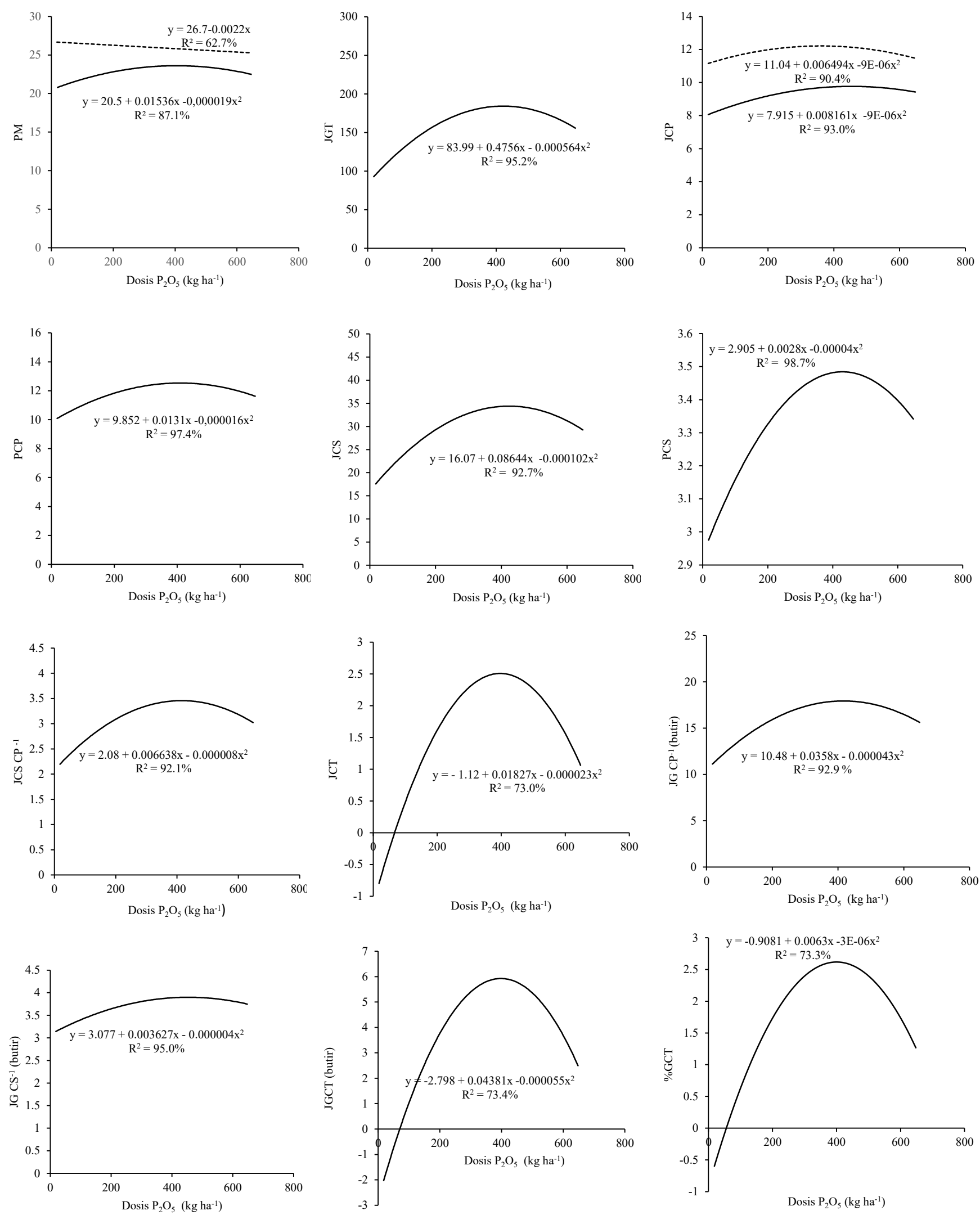

Gambar 4. Grafik pola respon karakter percabangan malai terhadap fosfor pada genotipe IPB158-5 dan genotipe IPB180-12. PM = panjang malai; JGT = jumlah gabah total; JCP = jumlah cabang primer; PCP = panjang cabang primer; JCS = jumlah cabang sekunder; $\mathrm{PCS}=$ panjang cabang sekunder; $\mathrm{PCS} \mathrm{CP} \mathrm{P}^{-1}=$ jumlah cabang sekunder per cabang primer; JCT $=$ jumlah cabang tersier; $\mathrm{JG} \mathrm{CP}^{-1}$ $=$ jumlah gabah per cabang primer; $\mathrm{JG} \mathrm{CS}^{-1}=$ jumlah gabah per cabang sekunder; JGCT $=$ jumlah gabah pada cabang tersier per malai; \%GCT $=$ persentase jumlah gabah pada cabang tersier per malai; garis penuh $(-)=\operatorname{IPB} 158-5$; garis putus-putus $(---)=$ IPB180-12 


\section{KESIMPULAN}

Unsur hara $\mathrm{P}$ berpengaruh terhadap karakter percabangan malai padi dan pengaruh $\mathrm{P}$ tersebut berbeda antar genotipe. Respon percabangan malai genotipe IPB1585 sensitif terhadap berbagai dosis $\mathrm{P}$ dan malai genotipe IPB180-12 kurang terpengaruh oleh tinggi rendahnya dosis P. Dosis P yang optimum untuk memperoleh jumlah gabah total per malai tertinggi adalah $421.63 \mathrm{~kg} \mathrm{ha}^{-1} \mathrm{P}_{2} \mathrm{O}_{5}$ pada genotipe yang sensitif terhadap $\mathrm{P}$, sedangkan pada genotipe yang tidak sensitif terhadap $\mathrm{P}$ adalah $108 \mathrm{~kg} \mathrm{ha}^{-1} \mathrm{P}_{2} \mathrm{O}_{5}$ pada kondisi $\mathrm{P}$ total maupun $\mathrm{P}$ tersedia rendah.

\section{UCAPAN TERIMA KASIH}

Terima kasih atas pendanaan dari Kemenristek Dikti penelitian skema PUPT 2017 nomor 011/SP2H/LT/DRPM/ IV/2017 atas nama Dr. Ir. Hajrial Aswidinnoor, M.Sc. dan kepada Badan Penelitian dan Pengembangan Pertanian Kementerian Pertanian sebagai sponsor beasiswa atas nama Tri Hastini.

\section{DAFTAR PUSTAKA}

Ahadiyat, Y.R., P. Hidayat, U. Susanto. 2014. Drought tolerance, phosphorus efficiency and yield characters of upland rice lines. Emir. J. Food Agric. 26:25-34.

Amanullah, Inamullah. 2016. Dry matter partitioning and harvest index differ in rice genotypes with variable rates of phosphorus and zinc nutrition. Rice Sci. 23:78-87.

Atakora, W.K., M. Fosu, S.O. Abebrese, M. Asante, M. Wissuwa. 2015. Evaluation of low phosphorus tolerance of rice varieties in northern Ghana. Sustainable Agric. Res. 4:109-114.

Bustami, Sufardi, Bakhtiar. 2012. Serapan hara dan efisiensi pemupukan phosfat serta pertumbuhan padi varietas lokal. J. Manaj. Sumberdaya Lahan 1:159-170.

Chiangmai, P.N., P. Yodmingkhwan. 2011. Competition of shoot and root growth between cultivated rice (Oryza sativa L.) and common wild rice (Oryza rufipogon Griff.) grown under different phosphorus levels. J. Sci. Technol. 33:685-692.

Fageria, N.K., A.M. Knupp, M.F. Moraes. 2013. Phosphorus nutrition of lowland rice in tropical lowland soil. Comm. Soil Sci. Plant Analysis 44:2932-2840.

Jeong, K., C. Julia, D.L.E. Waters, O. Pantoja, M. Wissuwa, S. Heuer, L. Liu, T.J. Rose. 2017. Remobilisation of phosphorus fractions in rice flag leaves during grain filling : implications for photosynthesis and grain yields. PLoS ONE 12:1-15.
Julia, C., M. Wissuwa, T. Kretzschmar, K. Jeong, T. Rosse. 2016. Phosphorus uptake, partitioning and redistribution during grain filling in rice. Ann. Bot. 118:1151-1162.

Kakade, D.P., J. Singh, M.R. Wallalwar, A. Janjal, A. Gupta, R. Raghuvanshi, M. Kongbrailatpam, S.B. Verulkar, S. Banerjee. 2017. Differential response of root morphology of rice (Oryza sativa L.) genotypes under different phosphorus conditions. Int. J. Curr. Microbiol. App. Sci. 6:149-160.

Kartina, N., B.P. Wibowo, I.A. Rumanti, Satoto. 2017. Korelasi hasil gabah dan komponen hasil padi hibrida. Penelitian Pertanian Tanaman Pangan 1:11-20.

Kekulandara, D.S., P.C.G. Bandaranayake, D.N. Sirisena, W.L.G. Samarasinghe, L.D.B. Suriyagoda. 2017. Temporal tillering behavior of Sri Lankan elite rice varieties in response to phosphorus availability. Trop. Agric. Res. 28:133-143.

Mohamed, K.A., A.E. Idris, H.I. Mohammed, K.A. Adam. 2012. Ranking rice (Oryza sativa L.) genotypes using multi-criteria decision making, correlation and path coefficient analysis. British Biotechnol. J. 2:211-228.

Mukherjee, A., S. Sarkar, A.S. Chakraborty, R. Yelne, V. Kavishetty, T. Biswas, N. Mandal, S. Bhattacharyya. 2014. Phosphate acquisition efficiency and phosphate starvation tolerance locus (PSTOL1) in rice. J. Genet. 93:683-688.

Nadeem, F., R. Ahmad, M.I.A. Rehmani, A. Ali, H.A. Bukhsh, J. Iqbal. 2015. Response of Basmati rice (Oryza sativa L.) yield to time of application of phosphorus in combination with zinc under anaerobic. Int. J. Adv. Res. Biol. Sci. 2:1-8.

Norain, M.N., A. Shamsiah, R.H. Abdul, A.H. Nor, A.M. Haslinda, A.W.A Wan A. 2014. Correlation analysis on agronomic characters in F2 population derived from MR64 and Pongsu Seribu 2. J. Appl. Sci. Agric. 9:143-147.

Panda, B.B., S. Sharma, P.K. Mohapatra, A. Das. 2012. Application of excess nitrogen, phosphorus, and potassium fertilizers leads to lowering of grain iron contentin high-yielding tropical rice. Comm. Soil Sci. Plant Analysis 43:2590-2602.

Peret, B., T. Desnos, R. Jost, S. Kanno, O. Berkowits, L. Nussaume. 2014. Root architecture responses: in search of phosphate. Plant Physiol. 166:1713-1723. 
Rahayu, S., M. Ghulamahdi, W.B. Suwarno, H. Aswidinnoor. 2018. Morfologi malai padi (Oryza sativa L.) pada beragam aplikasi pupuk nitrogen. J. Agron. Indonesia 46:145-152.

Rehim, A., M.Z. Hye, A. Imran, M.A. Ali, M. Hussain. 2014. Phosphorus and zinc application improves rice productivity. Pak. J. Sci. 66:134-139.

Vejchasarn, P., J.P. Lynch, K.M. Brown. 2016. Genetic variability in phosphorus responses of rice root phenotypes. Rice 9:1-16.
Weng, X., L. Wang, J. Wang, Y. Hu, H. Du, C. Xu, Y. Xing, X. Li, J. Xiao, Q. Zhang. 2014. Grain Number, Plant Height, and Heading Date7 is a central regulator of growth, development, and stress response. Plant Physiol. 164:735-747.

Yoseftabar. 2013. Effect of nitrogen and phosphorus fertilizer on spikelet structure and yield in rice (Oryza sativa L.). Intl. J. Agri. Crop Sci. 5:1204-1208.

Zhang, Y., C. Yu, J. Lin, J Liu, B. Liu, J. Wang, A. Huang, H. Li, T. Shao. 2017. OsMPH1 regulates plant height and improves grain yield in rice. PLoS ONE 12:117 . 